\title{
ANALISIS DAYA DUKUNG LAHAN PERTANIAN
}

\author{
Vicky R.B. Moniaga
}

\begin{abstract}
Analysis of the carrying capacity of agricultural land is an analysis to determine the carrying capacity of land to the caloric needs of the population. Analysis of the carrying capacity of agricultural land can also find out whether an area has or has not food self-sufficiency based on caloric needs of the population. The implication of this analysis is that it can find the optimal population that can be supported by existing agricultural land. From this analysis it can be seen that the area of crops and agricultural productivity are two factors that can increase the carrying capacity of agricultural land.
\end{abstract}

Keywords: Analysis, Carrying Capacity, Agricultural Land

\section{PENDAHULUAN}

\section{Latar Belakang}

Indonesia yang merupakan negara agraris, dengan sebagian besar penduduknya bekerja di sektor pertanian tentunya menggantungkan hidupnya pada lahan pertanian. Lahan pertanian sebagai tempat beraktifitas bagi petani semakin mengalami penurunan. Hal ini diakibatkan oleh semakin besarnya tekanan penduduk terhadap lahan pertanian. Jumlah penduduk yang terus meningkat dan aktifitas pembangunan yang dilakukan telah banyak menyita fungsi lahan pertanian untuk menghasilkan bahan makanan yang diganti dengan pemanfaatan lain, seperti pemukiman, perkantoran dan sebagainya. Akibatnya keadaan ini menyebabkan kemampuan lahan pertanian untuk memenuhi kebutuhan makanan bagi penduduk semakin berkurang.

Indonesia yang memiliki luas lahan pertanian yang tetap dengan pertumbuhan penduduknya yang besar akan menyebabkan ketersediaan lahan pertanian menjadi semakin kecil. Apabila hal ini dibiarkan, maka akan terjadi ketidakseimbangan penduduk yang bekerja sebagai petani pada suatu wilayah dengan luas lahan pertanian yang ada. Akibatnya, tekanan penduduk pada lahan pertanian akan semakin besar atau dengan kata lain wilayah tersebut tidak mampu lagi memenuhi kebutuhan pangan penduduknya.
Keadaan ini sangatlah kontradiktif, karena pertambahan penduduk membawa konsekuensi peningkatan kebutuhan bahan makanan dan ketersediaan bahan pangan merupakan hal yang penting dalam kehidupan. Oleh sebab itu, hal tersebut harus mampu dipenuhi oleh daerah dengan cara memanfaatkan dan meningkatkan potensi sumberdaya yang ada terutama lahan pertanian. Apabila keadaan ini dibiarkan berlangsung terus-menerus maka bukan tidak mungkin produksi sudah tidak sebanding dengan kebutuhan penduduk yang ada. Hal itu berarti bahwa daya dukung lahan pertanian akan semakin kecil.

Notohadiprawiro (1987) mengemukakan bahwa kemampuan lahan menyiratkan daya dukung lahan. Kemampuan lahan adalah mutu lahan yang dinilai secara menyeluruh dengan pengertian merupakan suatu pengenal majemuk lahan dan nilai kemampuan lahan berbeda untuk penggunaan yang berbeda. Dalam kaitannya dalam pemenuhan kebutuhan manusia, maka kemampuan lahan terjabarkan menjadi pengertian daya dukung lahan.

Imbangan tingkat pemanfaatan lahan dengan daya dukung lahan menjadi ukuran kelayakan penggunaan lahan. Sebaliknya jika pemakaian lahan telah melampaui kemampuan daya dukung lahan, maka pemanfaatan lahan tidak dipakai secara efektif. Dari uraian tadi, maka secara jelas dapat dikatakan bahwa daya dukung lahan adalah kemampuan bahan pada suatu satuan lahan untuk mendukung kebutuhan-kebutuhan manusia dalam 
bentuk penggunaan lahan, yang pada akhirnya tujuannya adalah untuk memenuhi kebutuhan manusia terutama bahan makanan.

Ida Bagus Mantra (1986), mengatakan bahwa penurunan daya dukung lahan dipengaruhi oleh jumlah penduduk yang terus meningkat, luas lahan yang semakin berkurang, persentase jumlah petani dan luas lahan yang diperlukan untuk hidup layak. Sedangkan untuk mengatasi penurunan daya dukung lahan menurut Hardjasoemantri (1989) dapat dilakukan antara lain dengan cara: 1). Konversi lahan, yaitu merubah jenis penggunaan lahan ke arah usaha yang lebih menguntungkan tetapi disesuaikan wilayahnya; 2). Intensifikasi lahan, yaitu dalam menggunakan teknologi baru dalam usahatani; 3). Konservasi lahan, yaitu usaha untuk mencegah.

Daya dukung lahan pertanian bukanlah besaran yang tetap, melainkan berubah-ubah menurut waktu karena adanya perubahan teknologi dan kebudayaan. Teknologi akan mempengaruhi produktivitas lahan, sedangkan kebudayaan akan menentukan kebutuhan hidup setiap individu. Oleh karena itu, perhitungan daya dukung lahan seharusnya dihitung dari data yang dikumpulkan cukup lama sehingga dapat menggambarkan keadaan daerah yang sebenarnya.

Variasi tingkat daya dukung lahan dan faktorfaktor yang mempengaruhinya disebabkan karena adanya perbedaan dalam aspek penduduk, sumber daya alam dan pengelolaan atau manajemen. Kenyataan ini mengisyaratkan bahwa penentuan kebijakan, terutama pemilihan dan penentuan alokasi sumber daya serta prioritas program untuk pembangunan harus dilakukan dengan hati-hati dan bijaksana dengan selalu memperhatikan situasi, kondisi dan potensi wilayah setempat.

Analisis daya dukung lahan pertanian perlu dilakukan untuk mengetahui kemampuan lahan untuk menyediakan pangan bagi pemenuhan kebutuhan penduduk di suatu daerah dan waktu tertentu. Tulisan ini bertujuan untuk menyajikan analisis daya dukung lahan pertanian dengan menggunakan contoh hasil penelitian oleh Kotambunan (2006) di Kabupaten Minahasa Provinsi Sulawesi Utara.

\section{TINJAUAN PUSTAKA}

\section{Daya Dukung Lahan}

Tanaman pangan adalah tanaman-tanaman yang menghasilkan bahan makanan utama seperti: padi (menghasilkan beras), palawija (menghasilkan jagung), kacang-kacangan dan ubi-ubian. Tanaman-tanaman dapat diusahakan di atas tanah, tanah sawah, ladang, ataupun pekarangan (Mubyarto, 1985). Sedangkan swasembada pangan merupakan usaha untuk memenuhi kebutuhan pangan sendiri dengan cara membudidayakan tanaman pangan seperti seleria (beras dan sejenisnya), palawija, cassava (ubi-ubian) dan lain-lain (Kusnadi dan Santoso dalam kamus istilah pertanian, 2000).

Notohadiprawiro (1987) mengemukakan bahwa kemampuan lahan menyiratkan daya dukung lahan. Kemampuan lahan adalah mutu lahan yang dinilai secara menyeluruh dengan pengertian merupakan suatu pengenal majemuk lahan dan nilai kemampuan lahan berbeda untuk penggunaan yang berbeda. Dalam kaitannya dalam pemenuhan kebutuhan manusia, maka kemampuan lahan terjabarkan menjadi pengertian daya dukung lahan.

Imbangan tingkat pemanfaatan lahan dengan daya dukung lahan menjadi ukuran kelayakan penggunaan lahan. Sebaliknya jika pemakaian lahan telah melampaui kemampuan daya dukung lahan, maka pemanfaatan lahan tidak dipakai secara efektif. Dari uraian tadi, maka secara jelas dapat dikatakan bahwa daya dukung lahan adalah kemampuan bahan pada suatu satuan lahan untuk mendukung kebutuhan-kebutuhan manusia dalam bentuk penggunaan lahan, yang pada akhirnya tujuannya adalah untuk memenuhi kebutuhan manusia terutama bahan makanan.

Ida Bagus Mantra (1986), mengatakan bahwa penurunan daya dukung lahan dipengaruhi oleh jumlah penduduk yang terus meningkat, luas lahan yang semakin berkurang, persentase jumlah petani dan luas lahan yang diperlukan untuk hidup layak. Sedangkan untuk mengatasi penurunan daya dukung lahan menurut Hardjasoemantri (1989) dapat dilakukan antara lain dengan cara : 1). Konversi lahan, yaitu merubah jenis penggunaan lahan ke arah usaha yang lebih menguntungkan tetapi disesuaikan wilayahnya; 2). Intensifikasi lahan, yaitu 
dalam menggunakan teknologi baru dalam usahatani; 3). Konservasi lahan, yaitu usaha untuk mencegah.

Daya dukung lahan pertanian bukanlah besaran yang tetap, melainkan berubah-ubah menurut waktu karena adanya perubahan teknologi dan kebudayaan. Teknologi akan mempengaruhi produktivitas lahan, sedangkan kebudayaan akan menentukan kebutuhan hidup setiap individu. Oleh karena itu, perhitungan daya dukung lahan seharusnya dihitung dari data yang dikumpulkan cukup lama sehingga dapat menggambarkan keadaan daerah yang sebenarnya.

Variasi tingkat daya dukung lahan dan faktorfaktor yang mempengaruhinya disebabkan karena adanya perbedaan dalam aspek penduduk, sumber daya alam dan pengelolaan atau manajemen. Kenyataan ini mengisyaratkan bahwa penentuan kebijakan, terutama pemilihan dan penentuan alokasi sumber daya serta prioritas program untuk pembangunan harus dilakukan dengan hati-hati dan bijaksana dengan selalu memperhatikan situasi, kondisi dan potensi wilayah setempat.

Keseimbangan daya dukung lahan pertanian pada penelitian ini diwujudkan dalam suatu keadaan dimana terdapat jumlah penduduk optimal yang mampu didukung oleh hasil tanaman pangan dari lahan pertanian yang ada di wilayah tersebut. Asumsi yang digunakan adalah selain jumlah dan pertumbuhan penduduk, maka faktor-faktor lain dianggap tetap, sehingga penurunan daya dukung lahan pertanian merupakan fungsi dari kenaikan jumlah penduduk. Luas lahan pertanian tahun 2000, sebesar 30 juta hektar. Bila dibandingkan dengan luas daratan Indonesia, memang luas lahan pertanian masih sangat rendah yaitu hanya 15,7 persen saja.

Hasil penelitian ini diharapkan dapat dimanfaatkan secara langsung dalam perencanaan pembangunan dan pembangunan tata ruang, dengan melihat variasi tingkat daya dukung lahan pertanian dari setiap wilayah penelitian. Selain itu dalam analisis, menggunakan data dari beberapa tahun sehingga diharapkan hasil yang didapat merupakan gambaran sebenarnya dari daerah penelitian, yang pada akhirnya dapat digunakan untuk perencanaan pembangunan Kabupaten Minahasa yang lebih baik.

\section{Tekanan Penduduk terhadap Lahan Per- tanian}

Kerusakan sumber daya alam dan lingkungan hidup yang terjadi selama ini berkaitan erat dengan tingkat pertambahan penduduk dan pola penyebaran yang kurang seimbang dengan jumlah dan pola penyebaran sumber daya alam serta daya dukung lingkungan yang ada (Moh. Soerjani, 1987).

Masalah kerusakan lingkungan yang paling kritis adalah tekanan penduduk terhadap terutama pada sektor pertanian. Masalah ini terus meningkat sejalan dengan waktu karena adanya pertambahan penduduk dan dipakainya terus lahan pertanian untuk pembangunan di sektor non pertanian. Akibatnya, pertumbuhan penduduk dan pemanfaatan lahan pertanian untuk pembangunan fisik untuk mendorong masyarakat untuk membuka lahanlahan pertanian baru yang menjadi salah satu penyebab bencana alam seperti longsor dan banjir.

Jumlah penduduk yang terus bertambah menyebabkan tingkat pertumbuhan tersebut jauh lebih tinggi dibandingkan tingkat pertambahan luas lahan untuk tanaman pangan. Faktor perilaku masyarakat terhadap lahan mempengaruhi daya dukung lahan itu sendiri. Di lihat dalam hal kependudukan meliputi kepadatan penduduk, migrasi penduduk komposisi penduduk seperti: (jenis kelamin, pendidikan, struktur umur dan mata pencaharian) serta penguasaan/ pemilikan tanah.

Penurunan kualitas sumber daya lahan akibat semakin kompleksnya permintaan kebutuhan pemilikan lahan atau pengolahan lahan mengakibatkan terjadinya penurunan daya dukung lahan. Penurunan daya dukung lahan dipengaruhi oleh jumlah penduduk yang terus meningkat, luas lahan yang semakin berkurang, persentase jumlah petani dan luas lahan yang diperlukan untuk hidup layak (Ida Bagus Mantra, 1986). Tekanan penduduk banyak terjadi di wilayah yang mempunyai kemampuan lahan rendah. Faktor-faktor yang mempengaruhi tekanan penduduk adalah struktur pekerjaan, kemampuan lahan dan kepadatan agraris.

Adanya pertambahan penduduk akan memerlukan pertambahan kebutuhan sandang, pangan dan papan. Ketidakseimbangan pertambahan penduduk dengan pertambahan kebutuhan sangat mempengaruhi keadaan lingkungan hidupnya, yaitu lingkungan akan dieksploitasi besar-besaran un- 
tuk memenuhi kebutuhan hidup. Akibatnya daya dukung lingkungan akan berkurang dan terjadi kerusakan lingkungan yang serius.

Pertumbuhan penduduk yang tinggi akan menimbulkan berbagai dampak di antaranya adalah meningkatkan kebutuhan lahan baik untuk pemukiman, sarana infrastruktur, dan lahan pertanian. Pada kenyataannya terjadi kecenderungan penyempitan lahan untuk pertanian sebagai imbas dari pembangunan fisik suatu daerah. Di sisi lain pertambahan penduduk yang terus meningkat akan memicu penurunan kapasitas daya dukung lahan pertanian.

Keberlanjutan daya dukung lahan sangat ditentukan oleh manusia pemilik atau pengelola lahan dan proses geomorfologi yang terjadi berupa erosi dan gerakan tanah, karena proses tersebut merupakan penyebab terjadinya degradasi lahan. Penggunaan lahan yang bersifat dinamis mempunyai kecenderungan merubah faktor-faktor topografi, tanah, dan batuan, hidrologi dan vegetasi. Perubahan tersebut ditentukan oleh kebutuhan hidup manusia dan dapat mengganggu fungsi lahan itu sendiri. Bentuk penggunaan lahan pada dasarnya adalah wujud nyata dari proses interaksi yang terjadi antara aktivitas-aktivitas manusia dan sumberdaya lahan dalam upaya untuk memenuhi kebutuhan dan meningkatkan taraf hidupnya (Soerjani, 1987).

Keterbatasan sumberdaya yang ada mengharuskan peran perencanaan pembangunan agar dapat mengatur penggunaan sumberdaya secara proporsional sehingga dapat tercapai kualitas lingkungan hidup yang optimal. Untuk mencapai ini harus ada keseimbangan antara jumlah penduduk dan luas lahan bersama sumberdaya yang dikandungnya, khususnya sumberdaya yang dapat diperbaharui pada lahan pertanian.

Dari luas daerah seluruh Indonesia 1,9 juta $\mathrm{km}^{2}$ atau 191 juta hektar, jumlah penduduknya pada tahun 1930 mencapai sekitar 60 juta jiwa dan pada tahun 2000 sudah menjadi 206,3 juta jiwa dengan pertambahan sebesar 1,49 persen per tahun (Adiratma, 2004). Pada tahun 2001, penduduk usia kerja atau berumur di atas 10 tahun sebanyak 144 juta penduduk di Indonesia. Dari total angkatan kerja sebesar 98,8 juta sekitar 91,9 persen telah bekerja dan sisanya masih mencari pekerjaan. Se- bagian besar dari mereka yang bekerja ternyata 77,78 persen berpendidikan rendah, sedangkan berpendidikan tinggi di SLTA hanya 4,81 persen. Jumlah penganggur mencapai 8 juta orang dan sekitar 56,61 persen dari mereka berpendidikan rendah dan 6,75 persen berpendidikan tinggi (Adiratma, 2004).

\section{ANALISIS DAYA DUKUNG LAHAN PERTANIAN}

\section{Perhitungan Kebutuhan Fisik Minimum}

Dalam suatu wilayah yang sama, daya dukung dapat berbeda karena cara pendekatannya yang berbeda. Untuk daerah-daerah yang sebagian besar penduduknya hidup dari sektor pertanian, daya dukung dihitung dari produksi bahan makanan. Segi perhitungannya dapat dihitung dari Kebutuhan Fisik Minimum (KFM) yang didasarkan atas kebutuhan kalori per orang per hari yaitu 2600 per orang per hari atau 265 kilogram beras per orang per tahun.

Pemahaman kalori sebagai dasar perhitungan atas pertimbangan bahwa untuk hidup sehat seseorang memerlukan sejumlah kalori tertentu yang berasal dari bahan makanan berbentuk bahan protein, lemak dan karbohidrat ditambah dengan mineral dan vitamin. Dengan dasar kalori ini, semua bahan makanan telah tercakup di dalamnya. Pertimbangan lain adalah karena hasil pertanian sebagian besar berupa karbohidrat seperti padi, jagung, ubi kayu, ubi jalar, kedelai dan kacang tanah yang merupakan sumber kalori terbesar dalam komposisi bahan makanan (Odum dkk., dalam Suhardjo dan Tukiran, 1990).

Nilai kebutuhan pokok fisik minimum adalah nilai yang menunjukkan seseorang dapat hidup secara normal, sehingga dapat bekerja untuk memenuhi kebutuhan hidupnya. Untuk itu diperlukan bahan makanan sebagai kebutuhan pokok manusia.

\section{Luas Lahan Tanaman Pangan yang Diperlukan per Kapita untuk Swasembada Pangan}

Luas lahan tanaman pangan yang dibutuhkan per kapita untuk swasembada pangan " $\mathrm{K}$ " (ha/orang) merupakan salah satu komponen yang sangat penting dalam perhitungan tingkat daya 
dukung lahan pertanian. Nilai $\mathrm{K}$ diperhitungkan dengan membagi nilai kebutuhan fisik minimum (KFM) dsengan produksi tanaman pangan per tahun yang tadinya dalam satuan ton, dikonversi menjadi kalori kemudian dikonversi lagi menjadi $\mathrm{kg}$ beras untuk tiap komoditi. Nilai ini akan dibandingkan dengan produksi tanaman pangan dari tiap daerah yang sudah dikonversi tadi sehingga satuannya menjadi kilogram beras/orang/tahun. Semakin kecil nilai $\mathrm{K}$ maka tingkat daya dukung lahan pertanian akan semakin baik. Luas lahan tanaman pangan yang dibutuhkan per kapita untuk swasembada pangan, nilainya selalu berubah-ubah menurut waktu dan ruang karena dipengaruhi oleh KFM dan kemampuan lahan untuk memproduksi tanaman pangan.

Semakin kecil nilai K maka kemampuan daya dukung lahan pertanian semakin besar. Untuk itu pada daerah-daerah yang memiliki nilai $\mathrm{K}$ tinggi diperlukan usaha untuk menurunkan angka tersebut melalui peningkatan produktivitas tanaman pangan atau memperluas areal tanaman pangan.

\section{Luas Panen Tanaman Pangan yang Tersedia per Kapita}

Komponen lain yang penting dalam perhitungan daya dukung lahan pertanian adalah luas panen tanaman pangan yang tersedia per kapita (X). Nilai $\mathrm{X}$ ini diperoleh dari luas panen tanaman pangan pada suatu daerah dibagi dengan jumlah penduduk pada daerah tersebut. Luas panen tanaman pangan ini nilainya selalu berubah-ubah baik antara daerah maupun antara waktu. Nilai X ini merupakan kebalikan dari nilai $\mathrm{K}$, karena semakin besar nilai $\mathrm{X}$ maka akan semakin baik tingkat daya dukung lahan pertanian di daerah tersebut

Daya dukung lahan yang seimbang ditentukan apabila luas lahan pertanian yang ada pada suatu wilayah dapat memenuhi kebutuhan fisik minimum penduduknya. Keseimbangan daya dukung lahan pertanian pada penelitian ini diwujudkan dalam suatu keadaan di mana jumlah penduduk optimal yang mampu didukung oleh hasil tanaman pangan dari lahan pertanian yang ada. Asumsi yang digunakan adalah selain jumlah dan pertumbuhan penduduk, maka faktor-faktor lain yang mempengaruhi dianggap tetap sehingga penurunan daya dukung lahan pertanian merupakan fungsi dari kenaikan jumlah penduduk. Nilai kebutuhan pokok fisik minimum adalah nilai yang menunjukkan seseorang dapat hidup sehat secara normal, sehingga dapat bekerja untuk memenuhi kebutuhan hidupnya, diperlukan bahan makanan sebagai kebutuhan pokok manusia.

\section{Teknik Analisis}

Teknik analisis data untuk menentukan tingkat daya dukung lahan pertanian digunakan rumus matematika dari konsep gabungan atas teori Odum, Christeiler, Ebenezer Howard dan Issard dalam Soehardjo dan Tukiran, 1990) yaitu:

$$
\sigma=\frac{X}{K}
$$

dimana: $\sigma=$ Tingkat daya dukung lahan pertanian

$\mathrm{X}=$ Luas panen tanaman pangan per kapita

$\mathrm{K}=$ Luas lahan untuk swasembada pangan

dengan:

$$
X=\frac{\text { Luas Panen (ha) }}{\text { Jumlah penduduk (jiwa) }}
$$

$$
K=\frac{\text { Kebutuhan Fisik Minimum (KFM) }}{\text { Produksi tanaman pangan/ha/tahun }}
$$

Oleh Odum dkk., dalam Soehardjo dan Tukiran (1990), wilayah yang mampu swasembada pangan adalah wilayah yang dapat memenuhi kebutuhan fisik minimum penduduk sebesar 1600 kalori/orang/hari atau setara dengan 265 kilogram beras/orang/tahun. Sedangkan untuk wilayah yang mampu memberikan kehidupan yang layak bagi penduduk yang tergantung pada tanaman pangan adalah wilayah yang dapat memenuhi kebutuhan penduduk dalam taraf yang layak yaitu setara dengan 650 kilogram beras/orang/tahun atau 2,466 kali KFM. Berdasarkan nilai-nilai tersebut maka klasifikasi yang ditetapkan adalah: 
1. Kelas I $\rightarrow \sigma>2,47:$

Wilayah yang mampu swasembada pangan dan mampu memberikan kehidupan yang layak bagi penduduknya.

2. Kelas II $\rightarrow 1 \leq \sigma \leq 2,7:$

Wilayah yang mampu swasembada pangan tetapi belum mampu memberikan kehidupan yang layak bagi penduduknya

3. Kelas III $\rightarrow \sigma<1$ :

Wilayah yang belum mampu swasembada pangan

Dari rumusan di atas maka dapat diturunkan rumus untuk mencari jumlah penduduk optimal (JPO) yang dapat didukung oleh hasil tanaman pangan dari lahan pertanian yang ada di wilayah tersebut, yaitu:

\section{$J P O=$ Daya Dukung Lahan $\times$ Jumlah Penduduk}

Hasil Penelitian yang dilakukan oleh Kotambunan, J., A., (2006) menunjukkan bahwa tingkat daya dukung lahan pertanian di Kabupaten Minahasa Tahun 2004 adalah.sebesar 1,25, atau berada kelas II menurut klasifikasi tingkat daya dukung lahan pertanian. Ini berarti Kabupaten Minahasa sudah mampu swasembada pangan tetapi belum mampu memberikan kehidupan yang layak bagi penduduknya. Selanjutnya, hasil penelitian Kotambunan, J., A., (2006) lainnya, yaitu bahwa pada Tahun 2004 di Kabupaten Minahasa, dari 15 kecamatan hanya Kecamatan Kakas dan Tompaso tingkat daya dukung lahan pertanian berada pada kelas I dimana pada kelas ini kedua kecamatan tersebut sudah mampu swasembada pangan dan mampu memberikan kehidupan yang layak bagi penduduknya. Secara lengkap, kecamatankecamatan di Kabuapten Minahasa menurut kelas daya dukung lahan pertanian tahun 2004 dapat dilihat pada Tabel 1.

Berdasarkan angka daya dukung lahan pertanian dan jumlah penduduk diperoleh jumlah penduduk optimal. Hasil penelitian Kotambunan, J., A., (2006) sebagaimana Tabel 2 memperlihatkan jumlah penduduk optimal yang dapat didukung oleh lahan pertanian di Kabuapaten Minahasa Tahun 2004.
Tabel 1. Kecamatan-kecamatan di Kabupaten Minahasa Menurut Klasifikasi Tingkat Day a Dukung Lahan Pertanian Tahun 2004

\begin{tabular}{|c|c|c|l|}
\hline Kelas & $\begin{array}{c}\text { Daya Dukung } \\
\text { Lahan Perta- } \\
\text { nian }\end{array}$ & $\begin{array}{c}\text { Jumlah } \\
\text { Keca- } \\
\text { matan }\end{array}$ & \multicolumn{1}{|c|}{ Kecamatan } \\
\hline I & $\sigma>2,47$ & 2 & Kakas, Tompaso \\
\hline II & $1<\sigma<2,47$ & 7 & $\begin{array}{l}\text { Langowan Ba- } \\
\text { rat, Langowan } \\
\text { Timur, Rembo- } \\
\text { ken, Kawang- } \\
\text { koan, Sonder, } \\
\text { Tondano Barat, } \\
\text { Tondano Timur }\end{array}$ \\
\hline III & $\sigma<1$ & 6 & $\begin{array}{l}\text { Tombariri, Eris, } \\
\text { Lembean Timur, } \\
\text { Kombi, Pine- } \\
\text { leng, Tombulu }\end{array}$ \\
\hline Total & - & 15 & \multicolumn{1}{|c}{-} \\
\hline
\end{tabular}

Sumber: Kotambunan, J., A., (2006)

Tabel 2. Jumlah Penduduk Optimal Menurut Kecamatan di Kabupaten Minahasa Tahun 2004

\begin{tabular}{|l|l|c|c|r|}
\hline No. & Kecamatan & $\begin{array}{c}\text { Jumlah } \\
\text { Pendu- } \\
\text { duk } \\
\text { (jiwa) }\end{array}$ & $\begin{array}{c}\text { Daya } \\
\text { Dukung } \\
\text { Lahan }\end{array}$ & $\begin{array}{c}\text { Jumlah } \\
\text { Penduduk } \\
\text { Optimal }\end{array}$ \\
\hline 1. & Langowan Barat & 22.017 & 1,57 & 34.567 \\
\hline 2. & Langowan Timur & 22.393 & 2,14 & 47.921 \\
\hline 3. & Kakas & 22.316 & 2,50 & 55.790 \\
\hline 4. & Tompaso & 15.128 & 2,57 & 38.879 \\
\hline 5. & Remboken & 10.939 & 1,22 & 13.346 \\
\hline 6. & Kawangkoan & 26.338 & 2,11 & 55.573 \\
\hline 7. & Tombariri & 25.765 & 0,36 & 9.275 \\
\hline 8. & Sonder & 18.020 & 1,50 & 27.030 \\
\hline 9. & Tondano Barat & 35.768 & 1,25 & 44.710 \\
\hline 10 & Tondano Timur & 14.402 & 1,75 & 25.204 \\
\hline 11 & Eris & 10.829 & 0,67 & 7.255 \\
\hline 12 & Lembean Timur & 8.803 & 0,50 & 4.402 \\
\hline 13 & Kombi & 11.974 & 0,50 & 5.987 \\
\hline 14 & Pineleng & 34.918 & 0,25 & 8.730 \\
\hline 15 & Tombulu & 13.918 & 0,50 & 6.959 \\
\hline & Kab. Minahasa & 293,528 & 1,25 & 366,910 \\
\hline Sul & &
\end{tabular}

Sumber: Kotambunan, J., A., (2006) 
Apabila jumlah penduduk optimal yang diperoleh lebih kecil dari jumlah penduduk yang terdata, maka diperlukan tambahan luas panen yang dapat mendukung penduduk tersebut. Selain tambahan luas panen, dapat juga dilakukan dengan cara peningkatan produksi tanaman pangan meialui usaha intensifikasi untuk mendukung penduduk tersebut.

\section{PENUTUP}

Dalam kaitannya dalam pemenuhan kebutuhan manusia, maka kemampuan lahan terjabarkan menjadi pengertian daya dukung lahan.

Analisis daya dukung lahan pertanian merupakan suatu analisis untuk mengetahui daya dukung lahan terhadap kebutuhan kalori penduduk. Analisis daya dukung lahan pertanian juga dapat mengetahui apakah suata daerah sudah atau belum swasembada pangan yang didasarkan pada kebutuhan kalori penduduk. Implikasi dari analisis ini adalah dapat mengetahui jumlah penduduk optimal yang dapat didukung oleh lahan pertanian yang ada. Dari analisis ini dapat diketahui bahwa luas panen dan produktivitas pertanian merupakan dua faktor yang dapat meningkatkan daya dukung lahan pertanian.

\section{DAFTAR PUSTAKA}

Adiratma, R, 2004. Stop Tanam Padi, Penebar Swadaya, Jakarta.
Hardjasoemantri, 1989. Hukum Tata Lingkungan. Edisi Ke-empat, Universitas Gadjah Mada Press, Yogyakarta.

Ida Bagoes Mantra, 1986. Pengantar Studi Demografi, Nur Cahaya, Yogyakarta.

Kotambunan, J, A, 2006. Daya Dukung Lahan Pertanian Tanaman Pangan di Kabupaten Minahasa. (Skripsi). Jurusan Sosial Ekonomi Fakultas Pertanian Universitas Sam Ratulangi, Manado.

Kusnadi dan Santoso, 2000. Kamus Istilah Pertanian. Cetakan Kelima, Kanisius, Yogyakarta.

Mubyarto, 1985. Pengantar Ekonomi Pertanian, LP3ES. Jakarta.

Muhammad Soerjani, 1987. Lingkungan Sumber Daya Alam dan Kependudukan Dalam Pembangunan. Universitas Indonesia Press, Jakarta.

Notohadiprawiro, 1987, Tanah, Tata Guna Lahan dan Tata Ruang Dalam Analisis Dampak Lingkungan, Universitas Gadjah Mada Press, Yogyakarta.

Suhardjo dan Tukiran, 1990. Studi Literatur Konsep yang Sudah ada Mengenai Daya Tam-

pung Wilayah. Kantor Menteri Negara Kependudukan dan Lingkungan Hidup, Jakarta.

Soerjani, 1987. Lingkungan: Sumberdaya Alam, Kependudukan, dalam Pembangunan, Universitas Indonesia Press, Jakarta. 
Lampiran 1. Daya Dukung Lahan Pertanian Kabupaten Minahasa Tahun 2004

\begin{tabular}{|c|c|c|c|c|c|c|c|c|}
\hline No. & Kecamatan & $\begin{array}{c}\text { Jumlah } \\
\text { penduduk } \\
\text { (jiwa) }\end{array}$ & $\begin{array}{l}\text { Luas panen } \\
\text { tanarnan } \\
\text { pangan (ha)* }\end{array}$ & $\begin{array}{c}\text { Produksi } \\
\text { tanaman } \\
\text { pangan } \\
(\mathrm{kg} \text { beras) })^{* *}\end{array}$ & $\begin{array}{c}\text { Produktivitas } \\
\text { tanaman } \\
\text { pangan } \\
\text { (kg beras) }\end{array}$ & Nilai X & Nilai K & $\begin{array}{c}\text { Daya Dukung } \\
\text { Lahan Pertanian }\end{array}$ \\
\hline 1. & Langowan Barat & 22.017 & 2.373 & 8.335 .000 & 3.512 & 0,11 & 0,07 & 1,57 \\
\hline 2. & Langowan Timur & 22.393 & 3.305 & 12.153 .000 & 3.677 & 0,15 & 0,07 & 2,14 \\
\hline 3. & Kakas & 22.316 & 4.466 & 15.486 .000 & 3.467 & 0,20 & 0,08 & 2,50 \\
\hline 4. & Tompaso & 15.128 & 2.725 & 9.796 .000 & 3.594 & 0,18 & 0,07 & 2,57 \\
\hline 5. & Remboken & 10.939 & 1.197 & 3.471 .000 & 2.899 & 0,11 & 0,09 & 1,22 \\
\hline 6. & Kawangkoan & 26.338 & 5.070 & 14.979 .000 & 2.954 & 0,19 & 0,09 & 2,11 \\
\hline 7. & Tombariri & 25.765 & 953 & 2.242 .000 & 2.352 & 0,04 & 0,11 & 0,36 \\
\hline 8. & Sonder & 18.020 & 2.102 & 7.082 .000 & 3.369 & 0,12 & 0,08 & 1,50 \\
\hline 9. & Tondano Barat & 35.768 & 3.498 & 12.061 .000 & 3.447 & 0,10 & 0,08 & 1,25 \\
\hline 10. & Tondano Timur & 14.402 & 2.078 & 7.050 .000 & 3.392 & 0,14 & 0,08 & 1,75 \\
\hline 11. & Eris & 10.829 & 615 & 1.714 .000 & 2.786 & 0,06 & 0,09 & 0,67 \\
\hline 12. & Lembean Timur & 8.803 & 515 & 1.165 .000 & 2.262 & 0,06 & 0,12 & 0,50 \\
\hline 13. & Eris & 11.974 & 576 & 1.497 .000 & 2.598 & 0,05 & 0,10 & 0,50 \\
\hline 14. & Pineleng & 34.918 & 636 & 2.044 .000 & 3.213 & 0,02 & 0,08 & 0,25 \\
\hline 15. & Tombulu & 13.918 & 640 & 1.637 .000 & 2.557 & 0,05 & 0,10 & 0,50 \\
\hline & Kab. Minahasa & 303.544 & 31.754 & 102.165 .000 & 3.217 & 0,10 & 0,08 & 1,25 \\
\hline
\end{tabular}

\section{Keterangan:}

* Luas panen tanaman pangan adalah penjumlahan dari luas panen padi, jagung, ubi kayu, ubi jalar, dan kacang tanah

** $1 \mathrm{~kg}$ beras=3.600 kalori, $1 \mathrm{~kg}$ jagung=3.610 kalori, $1 \mathrm{~kg}$ ubi kayu=1.460 kalori, $1 \mathrm{~kg}$ ubi jalar $=1.230$ kalori, dan $1 \mathrm{~kg}$ kacang tanah=4.520 kalori

Sumber: Kotambunan, J., A., (2006) 